\title{
Landsat TM image maps of the Shirase and Siple Coast ice streams, West Antarctica
}

\author{
Jane G. Ferrigno, Jerry L. Mullins, Jo Anne Stapleton, \\ U.S. Geological Survey, National Center, Reston, VA 22092, U.S.A.
}

ROBERT A. BINDSCHADLER, Code 971, NASA/Goddard Space Flight Center, Greenbelt, MD 20771, U.S.A.

T'ED A. SCAmbos,

National Snow and Lee Data Center, Lniversity of Colorado, Boulder, CO 80309-0449, U.S.A.

\author{
Lyxda B. Bellisime, Jo-AnN Bowell and Alex V. Acosta \\ U.S. Geological Survey, Flagstaff, AZ 86001, U.S.A.
}

\begin{abstract}
ABSTRAC'l. Fifteen 1:250000 and one 1:1000000 scale Landsat Thematic Mapper (TM) image mosaic maps are currently being produced of the West Antarctic ice streams on the Shirase and Siple Coasts. Landsat TM images were acquired between 1984 and 1990 in an area bounded approximately by $78^{\circ}-82.5^{\circ} \mathrm{S}$ and $120^{\circ}-$ $160^{\circ} \mathrm{W}$. Landsat $\mathrm{TM}$ bands 2,3 and 4 were combined to produce a single band, thereby maximizing data content and improving the signal-to-noise ratio. T'he summed single band was proccssed with a combination of high- and low-pass filters to remove longitudinal striping and normalize solar elevation-angle cffects. The images were mosaicked and transformed to a Lambert conformal conic projection using a cubic-convolution algorithm. The projection transformation was controled with ten weighted geodetic ground-control points and internal image-to-image pass points with annotation of major glaciological fcatures. The image maps are being published in two formats: conventional printed map sheets and on a CD-ROM.
\end{abstract}

\section{INTRODUGTION}

A series of Landsat image maps is being produced to support ongoing and future glaciological and geological research in the vicinity of "Ice Streams C, D, E and F", Shirase and Siple Coasts, West Antarctica (Bindschadler and others, 1988). Eightcen Landsat thematic mapper (TM) images were acquired from 1984 to 1990 between approximately $78^{\circ}$ and $82.5^{\circ} \mathrm{S}$ and $120^{\circ}$ and $160^{\circ} \mathrm{W}$. The images were mosaicked and processed by the USGS Image Processing Facility, Flagstaff; Arizona. The image mosaic covered sufficient area to produce 15 individual 1:250000 scale map sheets based on latitude and longitude guidelines established by the International Map of the World (IMW) geographic reference system. The nearly cloud-free image mosaic gives an excellent regional view of the entire area and will be released in digital format and as a 1:1000000 scale printed map.

\section{USGS MAPPING IN ANTARCTICA}

Since the mid-1940s, early maps relied on traditional mapping techniques using aerial photography and geographic control based on ground surveys from astronomical control points. A listing of USGS Antarctic maps, including satellitc-image maps, can be found in U.S. Geological Survey (1987).

When the first Landsat satellite was launched, it was immediately recognized that Landsat imagery would be able to improve greatly the accuracy and coverage of Antarctic mapping (Southard and MacDonald, 1974; MacDonald, 1976a). The satellite-image data cover all of Antarctica from the coastal areas to $82.5^{\circ} \mathrm{S}$ and allow mapping of areas previously unexplored (Williams and Ferrigno, 1988). Landsat imagery has been used to revise and update some of the earlier topographic maps (MacDonald, 1976c). The imagery is able to provide topographic detail without the expensive and timeconsuming process of air-brushing shaded relief. The imagery has been used with the sole addition of a geographic grid to produce an image map. It has also been used for map preparation after intensive digital processing to enhance features and transform geometric projection. It has also been used to provide base material for portraying other scientific information, such as geophysical data, blue-ice areas, geological and glaciological interpretation, velocity vectors and areas of coastal change (Lucchitta and Ferguson, 1986; Ferrigno and Gould, 1987; Lucchitta and others, 1987; Swithinbank, 1988; Ferrigno and Molnia, 1989; Ferrigno and others, 1993; Lucchitta and others, 1993).

Six satellite-image maps have been produced in color at 
1:250000 scale for areas around Ross Island and the Dry Valleys using Landsat 1 and 2 MSS imagery. Image maps of the McMurdo Sound region have bcen produced at scales ranging from $1: 250000$ to $1: 1000000$. With the launch of Landsat 4 in 1982 and Landsat 5 in 1984, which carried thematic mapper (TM) sensors, a marked improvement in geometric accuracy and increased pixel resolution $(28.5 \mathrm{~m})$ was achieved. The increased resolution satellite images, combined with the development of the Global Positioning System (GPS), has made it possible to revolutionize Antarctic mapping. The maps of the Shirase and Siple Coast area discussed here have utilized the Iandsat 4 and 5 TM imagery, but have relied on traditionally surveyed ground control and two Doppler-satellite positions, because GPS control has only recently begun to replace older surveying techniques in Antarctica and was not available for this area when the imagery was mosaicked.

At this date, LSGS map coverage extends from the base of the Antarctic Peninsula counter-clockwise along the coast almost to the Amery Ice Shelf. However, a project is currently under way that will producc 24 1: 1000000 scalc maps of the entire coastal regions of Antarctica based on Landsat 1, 2, 3, 4 and 5 imagery. The maps will show glaciologic features, ice-surface velocities and coastal change over a 15-20 year time span, and will comprehensively inventory outlet glacicrs and ice streams.

\section{IMAGE PROCESSING}

Landsat images used for this project are listed in Table 1. The 18 image mosaic was produccd using the USGS Mini Image Processing System (MIPS). Landsat TM bands 2, 3 and 4 were combined to maximize data content, improve the signal-to-noise ratio and produce a singleband product. A combination of high-pass and low-pass

Table 1: Landsat 4 and 5 TM imagery used in the Shirase and Siple Coast mapping project

PathiRow Scene I.D. Date Azimuth $\begin{gathered}\text { Sun } \\ \text { elevation }\end{gathered}$

\begin{tabular}{cccrc}
\hline $6 / 118$ & $50276-14544$ & 02 Dec 84 & 91 & 22 \\
$7 / 119$ & $51051-14510$ & 16 Jan 87 & 105 & 18 \\
$9 / 118$ & $51049-15025$ & 14 Jan 87 & 98 & 20 \\
$14 / 117$ & $51052-15333$ & 17 Jan 87 & 92 & 20 \\
$14 / 118$ & $51052-15335$ & 17 Jan 87 & 98 & 19 \\
$14 / 119$ & $42406-15472$ & 15 Feb 89 & 101 & 11 \\
$16 / 119$ & $51050-15464$ & 15 Jan 87 & 105 & 19 \\
$19 / 116$ & $51055-16040$ & 20 Jan 87 & 87 & 21 \\
$19 / 117$ & $42377-16170$ & 17 Jan 89 & 89 & 21 \\
$19 / 118$ & $42761-16172$ & 05 Feb 90 & 95 & 15 \\
$25 / 116$ & $51049-16410$ & 14 Jan 87 & 87 & 22 \\
$25 / 117$ & $51049-16412$ & 14 Jan 87 & 92 & 21 \\
$25 / 117$ & $51065-16415$ & 30 Jan 87 & 92 & 17 \\
$215 / 122$ & $51052-12174$ & 17 Jan 87 & 132 & 15 \\
$226 / 121$ & $50329-13355$ & 24 Jan 85 & 119 & 15 \\
$226 / 122$ & $50329-13362$ & 24 Jan 85 & 129 & 14 \\
$233 / 118$ & $42708-14203$ & 14 Dec 89 & 91 & 23 \\
$233 / 119$ & $51050-14074$ & 15 Jan 87 & 105 & 19 \\
\hline
\end{tabular}

filtering was used to remove the longitudinal striping noise present in the TM data that is quite obvious in lowcontrast arcas such as Antarctica. A separate high-pass filter $(201 \times 201)$ was applied to the data to suppress the difference in illumination across each scene caused by the position of the Sun in relation to the TM scanner. It was later determined that the use of this high-pass filter enhanced small topographic features and aided interpretation of flow dynamics but tended to "flatten" large topographic features such as ice domes and inter-icestream ridges. Further processing is planned to restore the appearance of large-scale topographic relief to the mosaic.

The individual images were geometrically transformed to a Lambert conformal conic projection using a cubicconvolution algorithm. The projection-transformation algorithm was controled with ten geodctic ground-control points and numerous internal image-to-image pass points. A least-squares approximation was derived that minimized adjustments between images. The calculated adjustments were only for translation and scale, producing errors as much as $300 \mathrm{~m}$ at some geodetic ground-control points. It was impossible to determine map accuracy in areas not covered by control points. Also, the distribution of the control points is not optimum. Most of the control points are located at the northwestern edge of the mosaic, where the rock outcrops are located. If more control were available on stationary or slowly moving ice features in the southern and eastern parts of the mosaic, the errors would have becn reduccd.

Before digital mosaicking, seam lines werc drawn using an interactive software package. The seam lines were placed to eliminate as much of the cloud and cloudshadow areas as possible and to give the best possible gray tone to match. After the images were mosaicked, the mosaic was contrast-stretched to further enhance subtle topographic features.

\section{GEODETIC CONTROL}

Bcfore the advent of satellite-positioning technology in the mid-1970s, a continent-wide network of geodetic control, such as that covering the U.S.A., did not exist for Antarctica. Rather than a single datum, numerous regional and local networks were established, each with an independently defincd datum established by astronomic methods. Stations of a network were connected to the astronomic stations by conventional terrestrial surveying methods.

By the method of astronomic and conventional terrestrial surveying, very useful geodetic control was established in support of USGS's Antarctic mapping projects (MacDonald, 1976b). Since most stations in these networks were rockbased, the networks are sparse due to large areas of ice between mountain ranges. Stations established on ice are subject to vertical and lateral movements. The unstable conditions for ice-based stations make them unsuitable for permanent geodetic control stations.

Nevertheless, internal consistency of the local and regional networks is very good, perhaps at the meter level relative to the astro-defined datum origin (astronomic observation station). Where there is no direct connection by terrestrial surveying methods to other control networks, inconsistencies on the order of $\sim 300 \mathrm{~m}$ between 
Table 2. Ground-control points used for Landsat image mosaic

\begin{tabular}{lccc}
\hline Control points & Latitude & Longitude & Survey method \\
\hline Mount Nilsen (Marlene) & $78^{\circ} 03^{\prime} 16^{\prime \prime} \mathrm{S}$ & $155^{\circ} 19^{\prime} 34^{\prime \prime} \mathrm{W}$ & Astronomic \\
Drummond Peak (X6S) & $77^{\circ} 51^{\prime} 19^{\prime \prime} \mathrm{S}$ & $153^{\circ} 58^{\prime} 13^{\prime \prime} \mathrm{W}$ & Astronomic \\
La Gorce Peak (E7S) & $77^{\circ} 37^{\prime} 31^{\prime \prime} \mathrm{S}$ & $153^{\circ} 41^{\prime} 35^{\prime \prime} \mathrm{W}$ & Astronomic \\
Mount Josephine (Tony) & $77^{\circ} 31^{\prime} 41^{\prime \prime} \mathrm{S}$ & $153^{\circ} 06^{\prime} 29^{\prime \prime} \mathrm{W}$ & Astronomic \\
McKinlcy Pcak (S5S) & $77^{\circ} 53^{\prime} 45^{\prime \prime} \mathrm{S}$ & $148^{\circ} 18^{\prime} 10^{\prime \prime} \mathrm{W}$ & Astronomic \\
Mount Monson (Court) & $77^{\circ} 30^{\prime} 27^{\prime \prime} \mathrm{S}$ & $143^{\circ} 30^{\prime} 58^{\prime \prime} \mathrm{W}$ & Astronomic \\
Lewisohn Nunatak & $77^{\circ} 38^{\prime} 24^{\prime \prime} \mathrm{S}$ & $142^{\circ} 49^{\prime} 14^{\prime \prime} \mathrm{W}$ & Astronomic \\
Moody Island (H6S) & $77^{\circ} 17^{\prime} 08^{\prime \prime} \mathrm{S}$ & $149^{\circ} 31^{\prime} 50^{\prime \prime} \mathrm{W}$ & Astronomic \\
Byrd Camp (Byrd) & $80^{\circ} 00^{\prime} 41^{\prime \prime} \mathrm{S}$ & $119^{\circ} 30^{\prime} 26^{\prime \prime} \mathrm{W}$ & Doppler \\
Ice Stream C (Knoll 1) & $82^{\circ} 21^{\prime} 22^{\prime \prime} \mathrm{S}$ & $153^{\circ} 38^{\prime} 53^{\prime \prime} \mathrm{W}$ & Doppler \\
& & & \\
\hline
\end{tabular}

networks sometimes exist. The astronomic positions defining each network datum are accurate to about $\sim 300 \mathrm{~m}$.

Ten geodetic control stations were used to control the image mosaic (Table 2). Two of the ten stations were at ice-based monuments. The remaining eight stations were established by USGS during the 1960s and based on the 1967 rock-based Snoopy astronomic fix. The coordinates were determincd by connections to the astro station using conventional traversing methods. Observations incorporated in the traverse adjustments included directions and vertical angles measured with theodolites, distances measured with electronic distance-measuring instruments and elevations measured with aneroid barometers.

\section{GARTOGRAPHIC PREPARATION}

Once the digital mosaic of the project arca was constructed, 15 individual 1:250000 scale map quadrangles were extracted based on the International Map of the World (IMW) gcographic-reference system. See Figure 1 for a sketch of the area covered by the quadrangles. Figure 2 is a black-and-white copy of one of the first five of the maps to be printed.

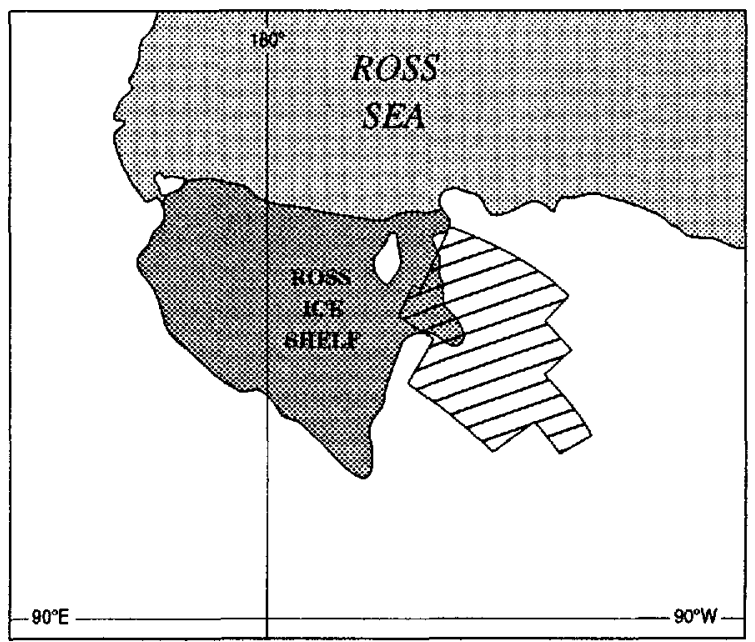

Fig. 1. Sketch map showing area covered by 151:250000 scale Landsal TM image maps of the Shirase and Siple Coast ice streams, West Antarctica.

\section{IMAGE INTERPRETATION}

The processing steps, while greatly enhancing the topographic featurcs, have introduced some minor artifacts into the image map. In a few instances, curved banding and striping can be seen on some inter-ice-stream ridges on the maps, a result of the contrast stretch applied over areas in which the unprocessed TM bands vary only by a few discrete brightness levcls.

An attempt was made to achieve an optimum compromise: to rcduce the artifacts as much as possible while still retaining most of the enhancement of the digital processing. The high-pass filter used to suppress the illumination variation tended to "flatten" the appearance of larger topographical features, such as the inter-icestream ridges and ice domes, relative to the smaller features within the ice streams. This effect is not especially noticeable on the individual map quadrangles but is much more obvious on the complcte mosaic. It was determined that this processing was advantageous for recognizing and interpreting small features and flow dynamics but that additional processing steps would be taken to restore the appearance of topographic relief to the image mosaic. Other artifacts gencrated by the high-pass filtering process sometimes appear on large-scale fcatures that have regional changes in slope. For example, ridge crests or ice grounding-lines may have additional apparent breaks in slope parallel to the main break in slope.

The images show sevcral features that are highly ephemeral or that move as the ice flows. Raggcd-cdged patches, particularly evident on inter-ice-stream ridges, indicate differences in the reflectance of the surface-snowcover due to grain-size variations and/or the presence of hoar frost on the surface. Fresh snow with its higher albedo appears as a lighter tone in the image than older snow (firn). The shape and location of these patches may change with every storm in the area. Individual crevasses and snow dunes within the ice streams are in motion at speeds up to $690 \mathrm{~m} \mathrm{a}^{-1}$, and have moved from the location they were in when the imagery was acquired. However, the general location and shape of entire crevasse fields, and of larger topographic undulations in the ice streams, are relatively fixed.

Although the image mosaic is predominantly cloudfree, there are a few clouds and cloud shadows which obscure some glaciologic features. Fven though the clouds 

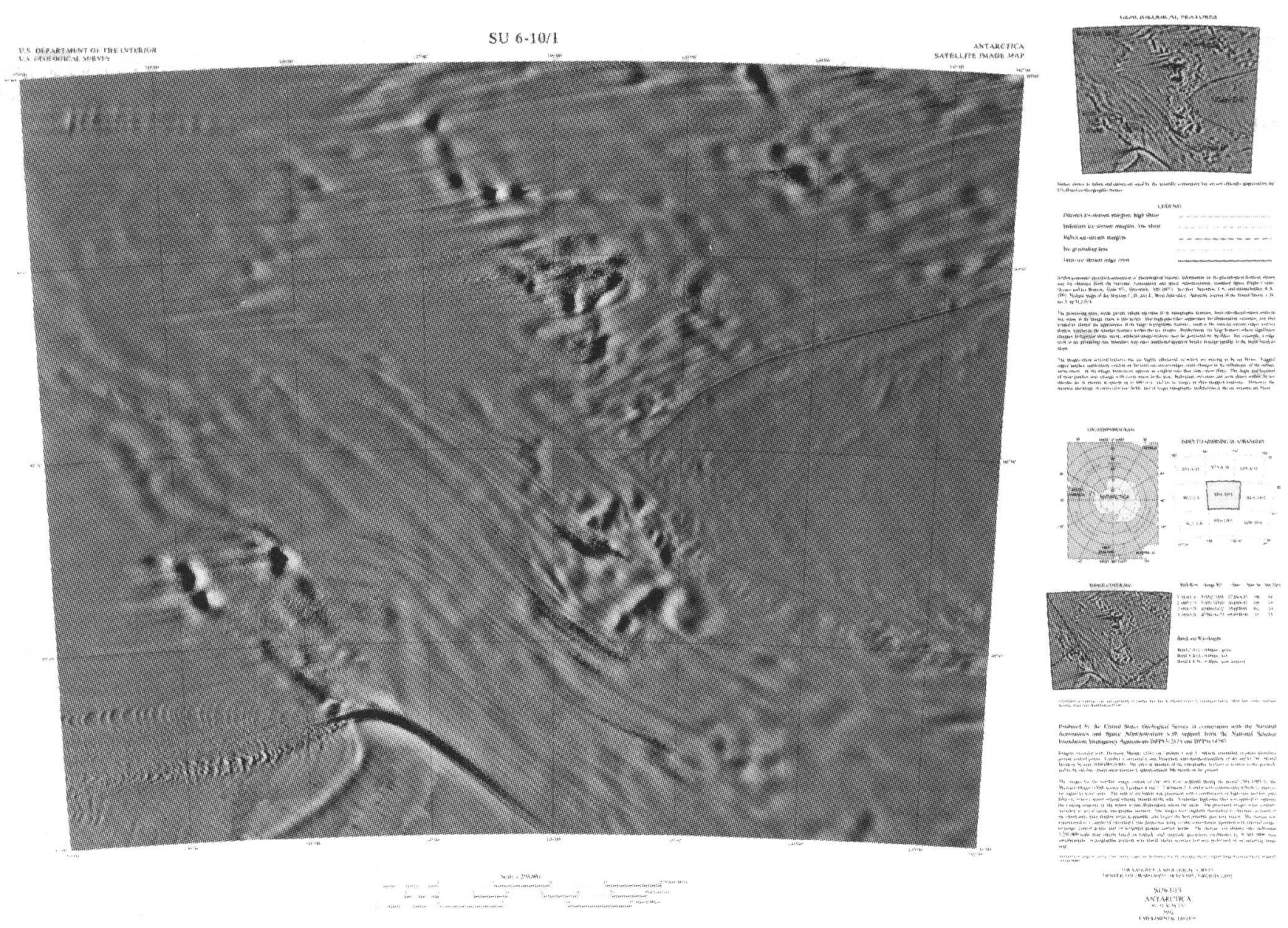

Fig. 2. Black-and-white photograph showing reduced $1 M W$ map sheet SU 6-10/1 covering part of Ice Stream E and interice-stream ridge E/F. Map sheet published at 1: 1250000 scale. Copyright U.S. Geological Survey.

may hide some features, it is generally possible to distinguish visually between clouds and surface features.

\section{GLACIOLOGIC FEATURES}

Interpretation and annotation of glaciologic features were based on inspection of the imagery (Scambos and Bindschadler, 1991) and field work through the 1991-92 field scason. The Landsat TM image mosaic extends east-west from Byrd Camp to Ross Ice Shelf and north-south from Sulzberger Bay and the Ford Ranges to about the middle of Ice Stream $\mathrm{C}$ at $82.5^{\circ} \mathrm{S}$. The glaciologic features in the region of the image mosaic include glaciers, ice streams, former ice strcams, inter-icestream ridges, crevasse fields, catchment areas and floating ice shelf (Fig. 3).

The Ross Icc Shelf is gencrally flat in appearance, although a group of ice rumples, previously noted by Swithinbank (1988) occur in front of Icc Streams D and E. Short troughs oriented normal to flow in the region immediately downstream of the grounding line of Icc Stream $E$ are attributed to the formation and gradual enlarging of bottom crevasses as the ice transfers from the grounded state to the floating statc. Flow bands and the crcvasse pattern of shear boundaries can be traced across the Ross Ice Shelf and perhaps used to reconstruct historic ice dynamics of the ice streams. Sulzberger Bay and Sulzberger Ice Shelf are visible at the northwestern edge of the mosaic but are partially obscured by clouds. Kiel Glacier, discharging into the Ross Ice Shelf on the western edge of the mosaic, appears about as wide as Ice Stream D at the grounding line but has a much smaller catchment area and probably a smaller discharge also Kiel Glacier and "Ice Stream F", smaller than Ice Streams A, B, C. D and $\mathrm{E}$, do not cxhibit the flow-strcaming appearance so noticeable on Ice Streams D and E.

The ice streams in the region are characterized by crevasses, relatively high-frequency and high-amplitude surface undulations, and a high density of flow bands. Former icc strcams (specifically, Ice Stream C) are similar in appearance but lack surface crevasses and, in general, have more subdued features due to burial by snow after rapid flow ccascd. Inter-ice-stream ridges are characterized by smooth to very slightly undulating surface topography with flow bands absent or very faint. Ridge "crests" are apparent on the imagery. It is easy to delineate ice streams and interice-stream ridges in the coastal areas but it becomes increasingly difficult to differentiate between the two in the upper reaches of the ice streams towards the eastern edge of the mosaic. The ice streams widen, their margins become more diffuse, flow bands become fewer and the undulations within the streams become more subdued. In the upstream regions, inter-ice-stream ridges are characterized by areas of slightly smoother topography bounded by ice containing very faint flow bands. 


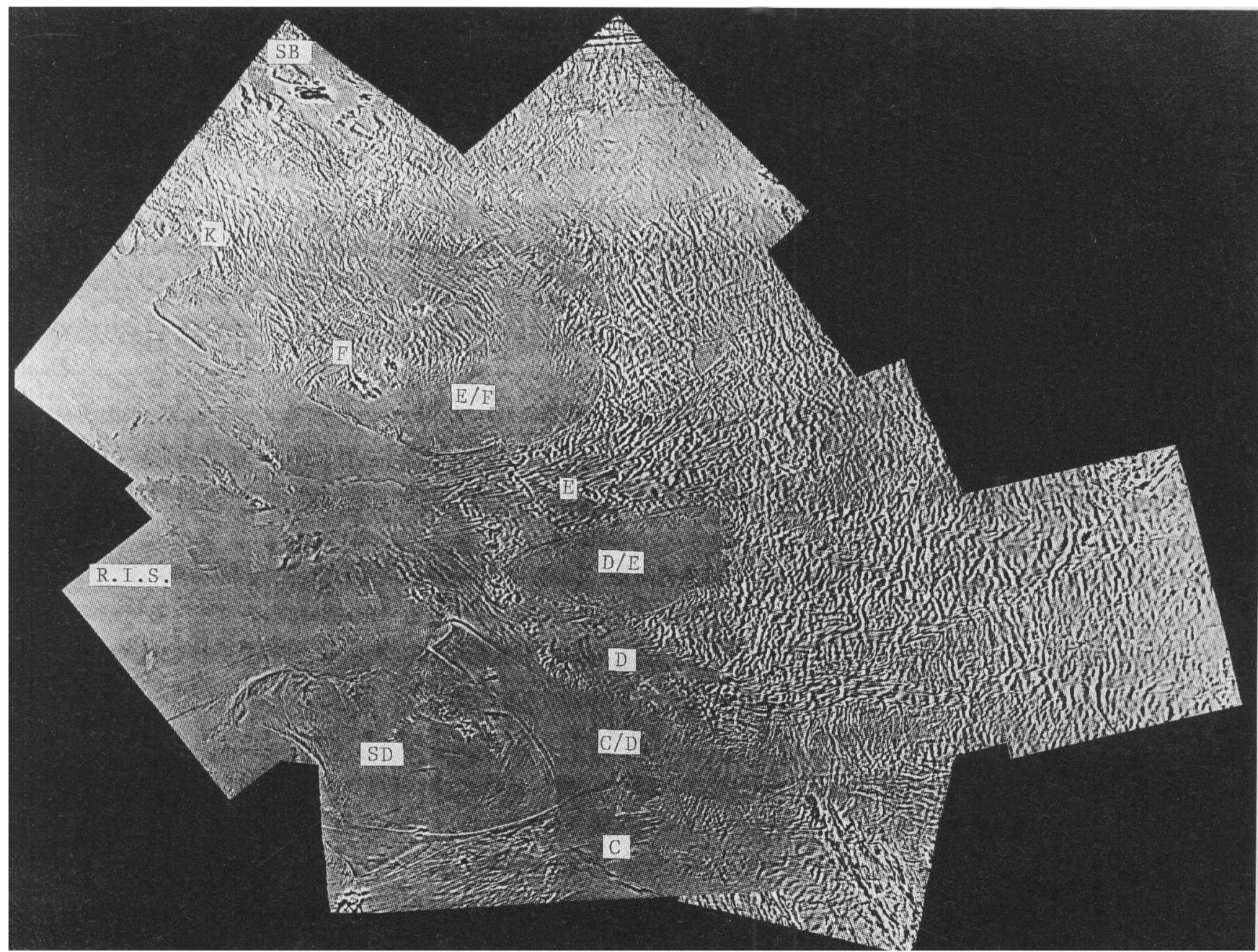

Fig. 3. Black-and-white photograph of a preliminary mosaic showing annotation of major glaciologic features. $C, D, E$ and F refer to ice streams. C/D, D/E and E/F are the inter-ice-stream ridges. R.I.S. is the Ros. Ice Shelf, SD is Siple Dome, $S B$ is Sulzberger Bay and $K$ is Kiel Glacier. Approximale scale is 1:4000000. Sulzberger Bay is the northernmost identified feature.

Flow features can be used in part to define the catchment areas of the ice streams. Flow features can be traced to the eastern cdge of the mosaic in the vicinity of Byrd Camp $\left(\sim 80^{\circ} \mathrm{S}, 120^{\circ} \mathrm{W}\right)$. However, it appears that there is no clear-cut boundary between the origin of one ice stream and another at least in the case of Ice Streams D and E). Instead, many small flow patterns interfinger (some appcaring more dynamic than others) and appear to move downstream around bedrock or slower-moving ice obstructions, gradually coalescing into well-defined ice streams.

Landsat imagery is valuable for interpreting many other features as well. The imagery provides better delineation of the grounding line (or grounding zone) at the outflow area of Ice Streams D and $\mathbf{E}$ than has been previously reported and refines the shape of the western margin of Siple Dome. Moreover, the images reveal several additional lincations on the northern and eastern sides of Siple Dome that are believed to represent relict ice-stream margins and flow bands (Fig. 4). If these features actually represent a different pattern of icestream flow, the cross-cutting relationships of these features and structures in Ice Stream C suggest the pattern must be older than the cessation of Ice Stream C, which is estimated to have ceased rapid flow $\sim 250$ years ago (Shabtaie and Bentley, 1987). Similar features are also observed near the mouth of Ice Stream C (Stephenson and Bindschadler, 1990).

A variety of boundaries are observed at the margins of the ice streams where they border the more slowly moving inter-ice-stream ridges. These are shown on the maps as two-boundary types, characterized by the estimated degree of shearing represented by ice motion at the interface. Boundaries mapped as solid lines are interpreted to have a high-shearing velocity contrast. Dashed lines indicate less-distinct boundaries interpreted to have a smaller, low-shearing velocity contrast. Boundaries of former ice streams are shown as dashed and dotted lines, with no attempt made to determine their former velocity or shear.

\section{CONCLUDING REMARKS}

The continent of Antarctica encompasses nearly $14 \times 10^{6} \mathrm{~km}^{2}$ and contains about $91 \%$ of the volume of glacier ice on Earth. It is clear that Landsat and other satellite imagery has much to offer scientific research in Antarctica. It can 


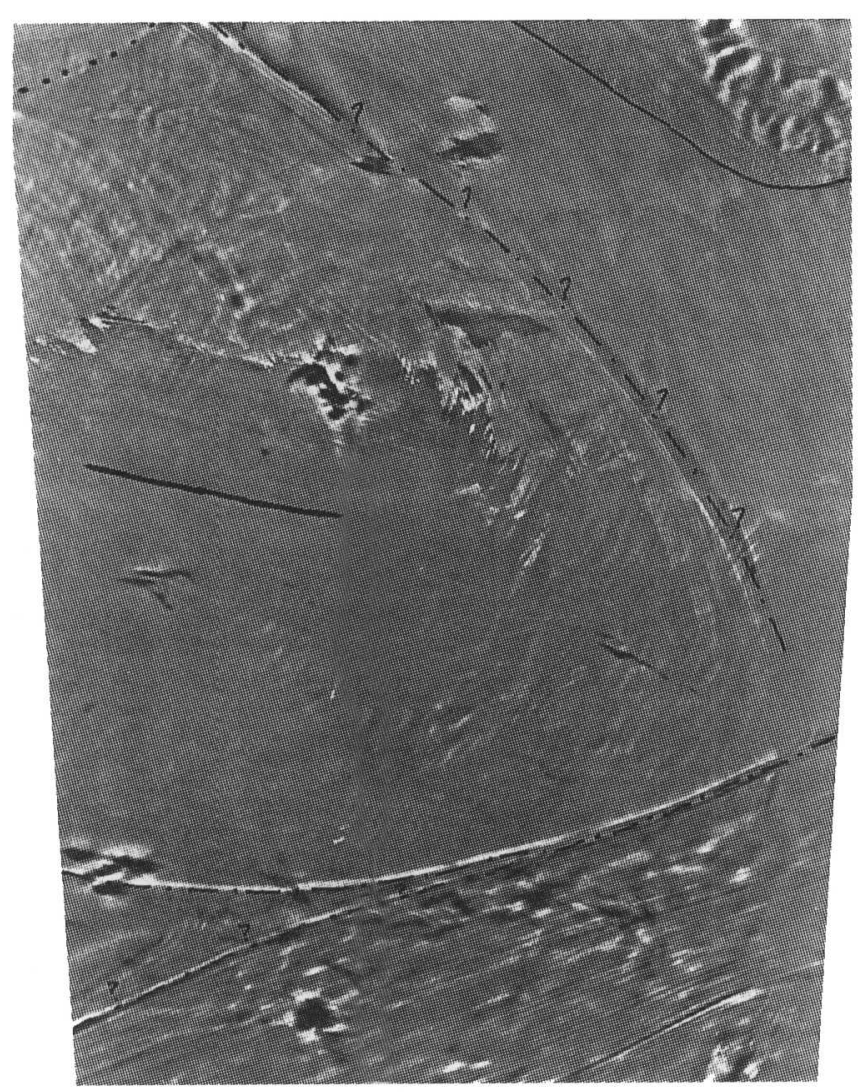

Fig. 4. Image of map quadrangle SU 6-1015-9* showing annotation of major glaciologic features. Siple Dome is in the center of the image. Ice Stream $C$ is at the bottom of the image and Ice Stream $D$ can be seen in the upper right corner. Possible relict boundaries are shown with question marks. Approximate scale is $1: 1300000$.

be used by cartographers in conjunction with GPS to produce the most accurate and cost-effective maps of this remote and incompletely mapped continent. It also offers glaciologists, geologists and other scientists photographic and digital data that can be used for mapping and interpretation of structure and dynamics (both present and historic), and of changes that may have occurred.

\section{ACKNOWLEDGEMENTS}

This project was supported in part by the U.S. National Science Foundation.

\section{REFERENCES}

Bindschadler, R.A., F.S. Brownworth and S. N. Stephenson. 1988. Landsat Thematic Mapper imagery of the Siple Coast, Antarctica. Antarct. F. U.S., 23(5), 214-215.

Ferrigno, J.G. and W. G. Gould. 1987. Substantial changes in the coastline of Antarctica revealed by satellite imagery. Polar Rec., 23(146), $577 \cdot 583$

Ferrigno, J.G. and B.F. Molnia. 1989. Availability of Landsal. Soyuzkarta, and SPOT data of Antarctica for ice and climate research. Antarct. F. U.S., $24(4), 1518$.

Ferrigno, J. G., B. K. Lucchitua, K. F. Mullins, A. L. Allison, R. J. Allen and W.G. Gould. 1993. Velocity measurements and changes in position of Thwaites Glacier/ice berg tongue from aerial photographs. Landsat images and NOAA AVHRR data. Ann. Glaciol., 17, 239-244.

Lucchitla, B.K. and H. M. Ferguson. 1986. Antarctica: measuring glacier velocity from satellite images. Science, 234(4780), 1105-1108.

Lucchitta, B. K., J.-A. Bowell, K. L. Edwards, E. M. Eliason and H. M. Ferguson. 1987. Multispectral Landsat images of Antarctica. L.S. Geol. Surv. Bull. 1696.

Lucchitta, B. K., K. F. Mullins, A. L. Allison and J. G. Ferrigno. 1993. $\Lambda$ ntarctic glacier-tonguc velocities from Landsat images: first results. Ann. Glaciol., 17, 356-366.

MacDonald, W. R. 1976a. Antarctic cartography, U.S. Geol. Surz. Prof. Pap. 929, 37-43.

MacDonald, W. R. 1976b. Geodetic control in polar regions for accurate mapping with ERTS imagery. U.S. Geol. Surv. Prof. Pap. 929, 34-36.

MacDonald, W. R. 1976c. Glaciology in Antarctica. U.S. Geol. Surt. Prof. Pap. 929, 194-195.

Scambos, T. A. and R. A. Bindschadler. 1991. Feature maps of ice streams C, D, and E, West Antarctica, Antarti. 7. U.S., 26 (5), 312-314.

Shabtaie, S. and C.R. Bentley. 1987. West Antarctic ice streams draining into the Ross Ice Shelf: configuration and mass balance. 7. Geophys. Res., 92(B2), 1311-1336.

Southard, R. B. and W. R. MacDonald. 1974. The cartographic and scientific application of ERTS-1 imagery in polar regions. $\mathcal{J}$. Res. U.S. Geol. Sury, 2 (4;, 385-394.

Stephenson, S. N. and R. A. Bindschadler. 1990. Is ice-stream evolution revealed by satellite imagcry? Ann. Glaciol., 14, 273-277.

Swithinbank, C. 1988. Satellite image atlas of glaciers of the world. Antarctica. U.S. Geol. Surt. Prof. Pap. 1386-B, 1-138.

USGS. 1987. Index to United States topographic and other map corerage of Antarctica. Washington, DC, Unitcd States Geological Survey.

Williams, R.S., Jr and J.G. Ferrigno. 1988. Landsat images of Antarctica. U.S. Geol. Surv. Prof. Pap. 1386-B, 139278.

The accuracy of references in the text and in this list is the responsibility of the authors, to whom queries should be addressed. 